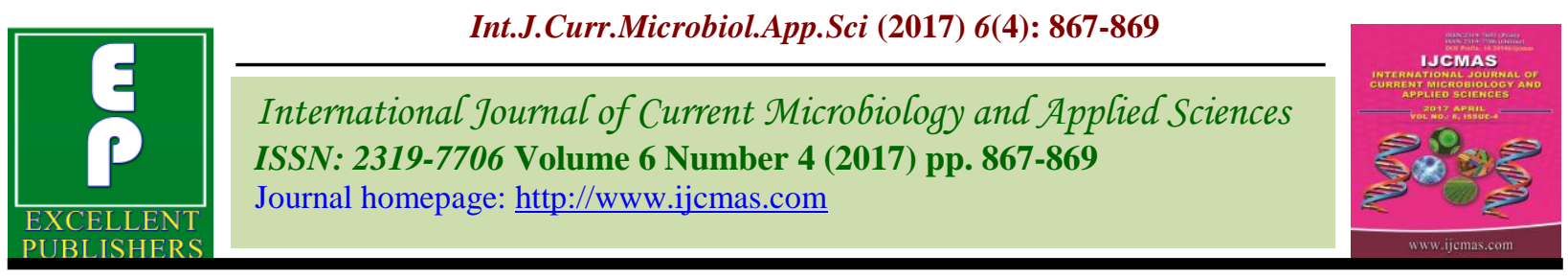

Original Research Article

https://doi.org/10.20546/ijcmas.2017.604.108

\title{
Transmission Studies of Soybean mosaic virus
}

\author{
H.V. Nandakishor*, Praful Kumar and S.S. Mane \\ Department of Plant Pathology, Dr. Panjabrao Deshmukh Krishi Vidyapeeth, \\ Akola, MS 444104, India \\ *Corresponding author
}

\begin{tabular}{|c|c|}
\hline & A B S T R A C T \\
\hline Keywords & \multirow{4}{*}{$\begin{array}{l}\text { The SMV was readily sap transmissible to Soybean cv. JS-335 when the } \\
\text { inoculum was prepared in } 0.1 \mathrm{M} \text { phosphate buffer ( } \mathrm{pH} 7.0 \text { ) and produce } \\
\text { typical symptoms such as mottling, crinkling of leaves, leaf puckering and } \\
\text { dwarfing. The cultivar JS- } 335 \text { was more susceptible to SMV than other } \\
\text { cultivars like PK- } 1029 \text { and MACS-13. The extract prepared from the leaves } \\
\text { of soybean proved to be most infectious containing the highest } \\
\text { concentrations of the virus as compared to the extracts obtained from other } \\
\text { plants parts (Stem and Root). }\end{array}$} \\
\hline $\begin{array}{l}\text { Soybean mosaic } \\
\text { virus, JS-335, } \\
\text { Transmision, } \\
\text { Mosaic and } \\
\text { mottling }\end{array}$ & \\
\hline Article Info & \\
\hline $\begin{array}{l}\text { Accepted: } \\
\text { 06 March } 2017 \\
\text { Available Online: } \\
10 \text { April } 2017\end{array}$ & \\
\hline
\end{tabular}

\section{Introduction}

Soybean [Glycine max (L.) Merrill] $(2 \mathrm{n}=40)$, is a species of legume native to East Asia (China), widely grown for its edible bean which has numerous uses. Soybean is called as "golden bean", "miracle bean", "crop of the planet" "super legume" of the $21 \mathrm{st}$ century. It is a versatile and fascinating crop with innumerable possibilities of not only improving agriculture but also supporting industries. Soybean is known to be naturally infected by at least 50 viral diseases belonging to different groups (Sinclair, 1992). In India, so far 11 viruses have been reported to occur on soybean (Mali, 1995). Virus diseases constitute the most serious disease threat to soybean production in many tropical areas. The most common virus of soybean around the world is soybean mosaic virus (SMV). It poses a constant threat to soybean production as it reduces the yield of field grown soybean by $25-100$ per cent. The ability of SMV to be transmitted through sap in future could become a limiting factor in expanding soybean cultivation in India. Hence, the present study was aimed to know the sap transmission means of spread of soybean mosaic virus in nature as well as under experimental conditions.

\section{Materials and Methods}

\section{Test plants}

Soybean cultivar JS-335 was used as test plant for mechanical transmission studies. These plants were raised from healthy seeds in six inch earthen and plastic pots containing the mixture of soil, sand and compost in 2:1:2 
ratio (w/w) and maintained in insect proof glasshouse. Four sets or 25 plants each were used for sap inoculation at four leaf stage.

\section{Preparation of inoculum}

Young leaves with characteristic mosaic symptoms were collected separately from the glasshouse infected soybean plants and from field conditions, for preparation of inoculum. These leaves were washed in tap water and dried between folds of blotting papers. The standard extract was prepared by macerating the infected plant material in a pre-chilled pestle and morter using $0.1 \mathrm{M}$ phosphate buffer ( $\mathrm{pH}$ 7.0) containing 0.1 per cent sodium sulphate @ 1ml/g of leaf tissue. The resultant pulp was squeezed through double layered muslin cloth. The extract thus obtained was used as a standard inoculum for inoculations.

\section{Method of inoculation}

For sap inoculation, young healthy vigorously growing seedlings were selected, a pinch of carborundum (600 mesh) was sprinkled onto leaves of test plants before inoculation as abrasive. A small piece of absorbent cotton, soaked in the extract was rubbed over the upper surface of the leaves, gently and unidirectionally. During the inoculation the leaves were supported from below by a piece of cardboard to avoid leaf injury and to assure uniform pressure and spread of inoculum. The inoculated leaves were washed immediately with a jet of distilled water using a squeeze bottle to remove the excess inoculum and abrasive. The plants were labeled and kept under observations for symptom development up to month in insect proof cages in glass house.

\section{Results and Discussion}

The results in table 1 revealed that SMV was sap transmissible and symptoms observed even up to one month. Whereas 70 per cent of the inoculated plants developed mosaic symptoms within 9-13 days alter inoculation (Table 1) this indicates that SMV not only aphids transmitted but also sap or mechanically transmitted. The SMV was readily sap transmissible to cv. JS-335 when the inoculum was prepared in $0.1 \mathrm{M}$ phosphate buffer ( $\mathrm{pH}$ 7.0) and produce typical symptoms such as mottling, crinkling of leaves, leaf puckering and dwarfing. The cultivar JS-335 was more susceptible to SMV than other cultivars like PK-1029 and MACS13. The rate of transmission was $68-80$ per cent. Similarly several workers have reported successful transmission of SMV by sap inoculation (Ali and Hassan, 1992; Naik and Keshavmurthy, 1997; Quinones, 1969; Shafik and Al-Jubori 1987 and Singh et al., 1976).

Table.1 Mechanical transmission of Soybean mosaic virus (cv.JS-335)

\begin{tabular}{|l|c|c|c|c|}
\hline Expt. No. & $\begin{array}{c}\text { No of plants } \\
\text { inoculated } \\
\text { (cv.JS-335) }\end{array}$ & $\begin{array}{c}\text { No of plants } \\
\text { infected }\end{array}$ & $\begin{array}{c}\text { Percent } \\
\text { transmission }\end{array}$ & $\begin{array}{c}\text { Periods taken for } \\
\text { symptoms } \\
\text { expression (days) }\end{array}$ \\
\hline 01 & 25 & 18 & 72 & $9-13$ \\
\hline 02 & 25 & 20 & 80 & $10-14$ \\
\hline 03 & 25 & 19 & 76 & $11-13$ \\
\hline 04 & 25 & 17 & 68 & $9-12$ \\
\hline Average & 25 & 18.5 & 74 & $9.75-13$ \\
\hline
\end{tabular}


Table.2 Sap transmission of SMV from different plant parts

\begin{tabular}{|c|c|c|}
\hline Sl. No & Extract from & Percent virus transmission \\
\hline 01 & Leaves & 49 \\
\hline 02 & Stems & 24 \\
\hline 03 & Root & 00 \\
\hline
\end{tabular}

The results in table 2 revealed that the extract prepared from the leaves of soybean proved to be most infectious containing the highest concentrations of the virus as compared to the extracts obtained from other plants parts (Stem and Root). These results regarding sap transmission were in agreement with those obtained in case of soybean mosaic disease caused by SMV (Gardner and Kendrick, 1921; Nariani and Pingaley, 1960; Singh, 1976; Gupta, 1975, and Naik and Murthy, 1997).

\section{References}

Ali, A. and Hassan, S. 1992. Biological characterization of soybean mosaic virus. Sarhad J. of Agri.8:555-561.

Gardner, M.W. and Kendrick, J. B. 1921. Soybean mosaic. J. of Agril. Res. 22:111-114.

Gupta, U.P. and Joshi, R.D. 1975. Analysis of the infection effect of soybean mosaic virus on growth of soybean. Acta Agronomica. 25:13-17.

Mali, V.R. 1995: Profile of viruses naturally infecting soybean in Marathawada. Abstracts and Souvenir, Proceedings of the 10th Annual Convention Indian Society for Virology and National Symposium: Viral Diseases of Socio-
Economic Importance Relevant to India, Jan. 16-18, SCTIMST, Dept. Microbiol, Trivandrum, India, pp: 34

Naik, R.G. and Keshavmurthy, R.V. 1997. Transmission of soybean mosaic virus through sap, seed and aphids. Karnataka J. of Agril. Sci. 10(2):565568.

Nariani, T.K. and Pingale, K.V. 1960. A mosaic disease of Soybean [Glycene $\max ($ L.) Merr.). Indian Phyt. 13: 130136.

Patil, R.G. and Byadgi, A.S. 2005. Transmission Studies of Soybean mosaic virus Karnataka J. Agric. Sci., 18(1):(52-54) 2005.

Quiniones, S.S. 1969. Soybean mosaic. Disease Abstracts, 29B:3157-3159.

Shafik, H.L. and Al-jubori, A.D. 1987. Identification of soybean mosaic virus on soybean in Iraq. Indian J. of Agric. and Water Resources Res. Plant Prod., 6(2):43-52.

Sinclair, J.B. 1992: Compendium of Soybean Diseases, 3 rd Edn., American Socity of Phytopathology. St. Paul, Minneosta, USA

Singh B.R., Singh, O.K. and Saxena, H.K. 1976. A mosaic disease of soybean at Kanpur, India. Science and Culture, 42: 53-54.

\section{How to cite this article:}

Nandakishor, H.V., Praful Kumar and Mane, S.S. 2017. Transmission Studies of Soybean mosaic virus. Int.J.Curr.Microbiol.App.Sci. 6(4): 867-869.

doi: https://doi.org/10.20546/ijcmas.2017.604.108 